\title{
Aboriginal Rights and State Obligations
}

\section{PATRICK MACKLEM}

This article investigates the nature and scope of Canada's constitutional obligations towards Aboriginal people. Specifically, the author explores the question of whether or not constitutional recognition of Aboriginal rights imposes a positive constitutional obligation on governments in Canada to provide economic or social benefits to Aboriginal people. He examines approaches which would either confirm or deny the existence of such an obligation and argues for a middle ground between these extremes which would require governments to provide some benefils in certain circumstances. Whether or not a particular social or economic benefit is required by $s$. 35(I) of the Canadian Constitution would depend on whether or not it is integral to the protection of one of the purposes or interests served by constitutional recognition and affirmation of Aboriginal rights in general. These purposes or interests include respect for Aboriginal identity, territory, and sovereignty. In addition, domestic fiduciary obligations and international human rights documents support the view that federal, provincial, and territorial governments ought to provide certain social and economic benefits to Aboriginals.
L'auteur étudie la nature et la portée des obligations constitutionnelles du Canada envers les peuples autochtones. Il se demande notamment si la reconnaissance constitutionnelle des droits autochtones impose aux gouvernements du Canada l'obligation constitutionnelle positive de fournir des avantages économiques ou sociaux aux peuples autochtones. Il examine des approches susceptibles de confirmer ou de nier une telle obligation, et propose une formule intermédiaire entre ces deux extrêmes au terme de laquelle les gouvernements devraient fournir certains avantages dans des circonstances données. Il s'agirait de déterminer les avantages exigibles aux termes du par. 35(I) de la Loi constitutionnelle de 1982, selon qu'ils relèvent ou non de la protection des fins ou intérêts faisant l'objet de la reconnaissance et de la confirmation des droits ancestrawx en général. Ces fins ou intérêts incluent le respect de l'identité, du territoire et de l'autonomie gouvernementale des autochtones. Les obligations de fiduciaire de l'État et les documents internationaux relatifs aux droits de la personne appuient également la conclusion voulant que les gouvernements fédéral, provinciaux et territoriaux soient tenus de fournir certains avantages sociaux et économiques aux autochtones.

\section{TABLE OF CONTENTS}

I. INTRODUCTION $\ldots \ldots \ldots \ldots \ldots \ldots \ldots \ldots \ldots \ldots \ldots$

II. General Constitutional Principles $\ldots \ldots \ldots \ldots \ldots \ldots \ldots 99$

A. Negative Rights versus Positive Rights . . . . . . 100

B. Civil aNd Political RightS Versus Social

AND ECONOMIC RIGHTS . . . . . . . . . . . . . 102

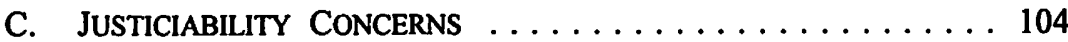

III. Positive Dimensions of ABORIGINAL RIGHTS $\ldots \ldots \ldots \ldots \ldots 106$



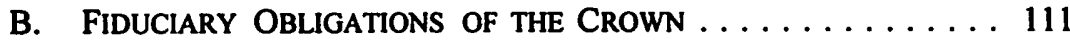

C. INTERNATIONAL LEGAL OBLIGATIONS $\ldots \ldots \ldots \ldots \ldots \ldots 113$

D. INSTITUTIONAL COMPETENCE REVISITED $\ldots \ldots \ldots \ldots \ldots 115$

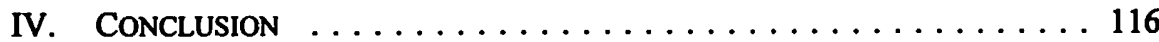

Associate Professor, Faculty of Law, University of Toronto. Earlier versions of this article were presented before the Royal Commission on Aboriginal Peoples and the 1997 Annual Conference of the Inter-American Bar Association. 


\section{INTRODUCTION}

Section 35(1) of Canada's Constitution Act, 1982 provides that "[t]he existing aboriginal ... rights of the aboriginal peoples of Canada are hereby recognized and affirmed." This article is a reflection on the following question: does constitutional recognition of Aboriginal rights impose positive constitutional obligations on federal, provincial or territorial governments in Canada to provide economic (such as funding) or social (such as health care or education) benefits to Aboriginal people? In the process, I hope to shed light on some problems relating to the definition and scope of Aboriginal rights recognized by s. 35(1) of the Constitution Act, 1982 in the context of social and economic policy.

One possible approach to this question is to deny that Aboriginal rights recognized by s. 35(1) include requiring non-Aboriginal governments to provide certain social and economic benefits to Aboriginal people. Properly understood, s. 35(1) rights are negative rights, in that they prevent government from interfering with their exercise. Concerns relating to judicial legitimacy and judicial competence militate against interpreting s. 35(1) to require governments to provide social and economic benefits to Aboriginal people. Any benefits in this regard would have to be the product of negotiation or legislation. If negotiated, such benefits could constitute treaty rights and receive recognition as such by $\mathrm{s}$. 35 . If legislated, such benefits could be withdrawn or altered without the consent of Aboriginal peoples.

An opposite approach would be to suggest that Aboriginal rights recognized by $s$. 35 include rights to a wide array of social and economic benefits from federal, provincial or territorial governments. This approach likely would be guided by three ideas. First, it would extrapolate generous positive rights from the fact of a fiduciary relationship between the Crown and Aboriginal peoples. Second, it would be guided by the intuition that it is unfair to constitutionally distribute social and economic benefits only to those Aboriginal peoples sufficiently powerful or fortuitous enough to enjoy either the benefit of treaty protection or legislative goodwill. Third, it would likely tap into principles of restitution to suggest that the Canadian state ought to be constitutionally obliged to undo the damage wrought by colonization and ameliorate Aboriginal socio-economic disadvantage.

This article attempts to steer a middle course between these two extremes. It will be argued that s. 35(1) constitutionally recognizes more than what are often referred to as negative rights, i.e., rights to be free of at least some forms of federal, provincial, and territorial regulation, and that rights recognized by $\mathrm{s} .35(1)$ possess positive dimensions. Such positive dimensions may include requiring government in some circumstances to provide certain social and economic benefits to Aboriginal people. Whether a particular social or economic benefit is required by s. 35(1) will depend on whether it is integral to one or more of the purposes or interests served by the constitutional recognition and affirmation of Aboriginal rights. In this light, whether s. 35 recognizes Aboriginal rights to social or economic benefits from federal, provincial or territorial governments is a 
question that ought to be tied to the deeper purposes of s. 35, which this article argues include respect for Aboriginal identity, territory and sovereignty.

Part II of this article locates this issue in light of a number of general constitutional principles. It provides an overview of debates surrounding the distinction between positive and negative constitutional rights, and the distinction between civil and political rights and social and economic rights. It advances the claim that all constitutional rights possess positive dimensions. As a result, the key question is not whether Aboriginal rights possess positive dimensions, but instead whether the positive dimensions of Aboriginal rights include governmental obligations to provide social and economic entitlements. This part also identifies two types of arguments commonly employed to challenge claims that constitutional rights impose positive social and economic obligations on government, namely, arguments that question either the legitimacy or the competence of the judiciary to render such judgments.

Part III focuses on the positive dimensions of Aboriginal rights. It examines a number of possible approaches to the question of what constitutes an Aboriginal right recognized by s. 35(1), based on recent Supreme Court of Canada jurisprudence. It argues that the underlying purposes of s. 35(1) include respect for Aboriginal identity, territory and sovereignty. Respect for Aboriginal identity underlies constitutional recognition of certain Aboriginal practices. Respect for Aboriginal territory justifies constitutional recognition of Aboriginal title. Finally, respect for Aboriginal sovereignty supports constitutional recognition of Aboriginal self-government. When viewed in light of the Crown's fiduciary obligation and emergent international legal standards, these deeper purposes of s. 35(1) may well require governments to provide certain social and economic benefits to Aboriginal people.

Two caveats are in order. First, this article is exploratory in nature. Given the scarcity of case law and scholarship on the subject, any conclusions it offers are speculative and necessarily tentative. Second, it does not seek to identify what social and economic benefits in fact are required by s. 35(1). As a result, its approach is relatively conceptual and abstract. Nonetheless, my hope is that it will foster greater understanding of the nature and scope of Canada's constitutional obligations toward Aboriginal people.

\section{General Constitutional Principles}

Aboriginal rights may well differ in many respects from other types of constitutional rights, but whether they impose positive obligations on government is a familiar question in constitutional interpretation. Courts often wrestle with this issue when seeking to define the nature and scope of constitutional guarantees. Two distinctions tend to dominate the field. The first is a distinction between negative rights and positive rights. The second is a distinction between civil and political rights and social and economic rights. Courts also tend to be concerned about institutional legitimacy and institutional competence when confronted with claims that government owes positive constitutional obligations to provide social and economic benefits. The remainder of this part explores the meaning of these distinctions and concerns in order to situate 
questions relating to the nature and scope of Aboriginal rights within the broader context of constitutional interpretation.

\section{A. Negative Rights versus Positive Rights}

Whether Aboriginal rights require governments to provide social and economic benefits to Aboriginal people is a question that implicates a well-known, but elusive, distinction between negative and positive rights. ${ }^{2}$ The distinction is said to speak to the nature of the obligation that rights create. A negative right creates an obligation of inaction or non-interference. As against the state, a negative right requires government not to interfere with its exercise. A positive right requires action instead of inaction. Positive rights typically require government to provide certain benefits to the rightholders in question. Proponents of the view that Aboriginal rights require governments to provide social and economic benefits to Aboriginal people may well seek to characterize s. 35 rights as positive rights, whereas opponents may seek to characterize s. 35 rights as negative rights.

An example of how the distinction between positive and negative constitutional rights works in practice can be found in Harris v. McRae, ${ }^{3}$ where the United States Supreme Court upheld a woman's negative right to undergo an abortion, but rejected the claim that women had a positive right to state-funded abortions even if necessary to save a woman's life. Similarly, in DeShaney v. Winnebago County Department of Social Services, ${ }^{4}$ the United States Supreme Court dismissed the claim that state officials violated the Constitution when they failed to protect a child from imminent harm, since the government, according to the Court, normally has no positive duties to protect citizens from imminent danger. ${ }^{5}$

Although popular south of the border, the distinction between negative and positive rights enjoys less currency in Canadian constitutional thought. Canadian political culture has traditionally been wary of libertarian premises that appear to underpin the distinction between negative and positive rights, and is more accepting of state action designed to promote individual and collective well-being. ${ }^{6}$ As stated by Wilson J. in McKinney v. University of Guelph,

Canadians have a somewhat different attitude towards government and its role from our U.S. neighbours. Canadians recognize that government has traditionally had and continues to have an important role to play in the creation and preservation of a just Canadian society. The state has been

2 Compare I. Berlin, "Two Concepts of Liberty" in I. Berlin, Four Essays on Liberty (London: Oxford University Press, 1969) 118 at 121-72 (distinguishing between positive and negative freedom).

3448 U.S. 297 (1980).

489 U.S. 189 (1989).

5 See also Jackson v. City of Joliet, 715 F.2d 1200 at 1203 (para. 11) (7th Cir. 1983), cert. denied 465 U.S. 1049 (1984), Posner J. ("the Constitution is a charter of negative rather than positive liberties").

6 See generally G. Horowitz, Canadian Labour in Politics (Toronto: University of Toronto Press, 1968); see also P. Macklem, “Constitutional Ideologies" (1988) 20 Ottawa L. Rev. 117. 
looked to and has responded to demands that Canadians be guaranteed adequate health care, access to education and a minimum level of financial security to name but a few examples. ${ }^{\text {? }}$

Moreover, at a conceptual level, the distinction between negative and positive rights is less sturdy than it initially might appear. A negative right is said to protect a rightholder from certain forms of state action, but the freedom that such a right protects does not exist independently of, and apart from, state action. A right of privacy, for example, initially presents itself as a negative right, in that it suggests that governments should not act in certain ways. However, a right of privacy also requires state action in the form of the establishment and enforcement of a host of background property and contractual entitlements. ${ }^{8}$ Property law prevents individuals from violating the privacy of others. Contract law protects the freedom of individuals to refuse to contract with other people. Characterizing a right of privacy as a negative right ignores the myriad forms of state action embedded in the freedom contemplated by the right. ${ }^{9}$

In light of these cultural and conceptual shortcomings, the distinction between negative and positive rights is of limited utility in understanding the nature of constitutional rights in Canada. However, the distinction should not be jettisoned entirely. While not helpful as a means of distinguishing one type of right from another, the distinction is useful in identifying and labelling a right's dimensions. Rights are rarely if ever purely negative or positive. Instead, they possess negative and positive dimensions. A right's positive and negative dimensions will vary according to the interests it protects. A right's positive dimensions require government to act in certain ways, whereas its negative dimensions require government to refrain from acting in other ways.

Canadian courts have not shied away from holding that rights guaranteed by the Charter of Rights and Freedoms possess positive as well as negative dimensions. Some rights clearly contemplate positive obligations on government. For example, minority language educational rights contained in the Charter impose "positive obligations on government to alter or develop major institutional structures." ${ }^{10}$ Similarly, legal rights, such as the right to a fair trial, the right not to be subject to cruel and unusual punishment, and the right to counsel, tend to require certain action and expense on the part of government. $R$ v. Askov" is a striking example of the positive dimensions of legal rights. In Askov, the Supreme Court of Canada held a delay of up to two years

[1990] 3 S.C.R. 229 at 356 [hereinafter McKinney].

See generally C.R. Sunstein, The Partial Constitution (Cambridge: Harvard University Press, 1993) at 93-122.

See S. Bandes, "The Negative Constitution: A Critique" (1990) 88 Mich. L. Rev. 2271; D.P. Currie, "Positive and Negative Constitutional Rights" (1986) 53 U. Chi. L. Rev. 864. Compare the following statement by Wilson J.:

It is, in my view, untenable to suggest that freedom is co-extensive with the absence of government. Experience shows the contrary, that freedom has often required the intervention and protection of government against private action.

McKinney, supra note 7 at 356.

See Mahe v. Alberta, [1990] 1 S.C.R. 342 at 365.

[1990] 2 S.C.R. 1199. 
between the date of committal for trial and the trial itself to be in violation of an accused's right to be tried within a reasonable time. Although the Court did not order the government to build new court facilities, it did suggest the adaptation of government buildings or portable structures to serve as courthouses.

Other Charter rights contain less straightforward positive dimensions but nonetheless have been held to require state action. For example, "the right to life, liberty and security of the person is in one sense a negative right, but the requirement that the government respect the 'fundamental principles of justice' may provide a basis for characterizing s. 7 [of the Charter] as a positive right in some circumstances."12 Equality rights are often thought of in similarly ambivalent terms:

The equality right is a hybrid of sorts since it is neither purely positive nor purely negative. In some contexts it will be proper to characterize $s$. 15 [of the Charter] as providing positive rights. ${ }^{13}$

If it is true that all constitutional rights possess positive as well as negative dimensions, then the key question is not whether a particular right is positive or negative. It is instead whether the right's positive dimensions include the particular governmental obligation at issue. ${ }^{14}$ Translated to the context of s. 35 , the question is not whether s. 35 recognizes and affirms positive constitutional rights, but instead whether the positive dimensions of the rights recognized and affirmed by $\mathrm{s} .35$ include governmental obligations to provide social and economic benefits to Aboriginal people. An answer to this question will depend in part on the nature of the interests that $\mathbf{s}$. 35 ought to protect.

\section{B. Civil and Political Rights versus Social AND ECONOMIC RIGHTS}

Whereas the distinction between negative and positive rights is said to involve differing obligations, civil and political rights and social and economic rights differ in terms of the interests they protect. Civil and political rights typically refer to freedom of expression, conscience, religion, assembly, and association, as well as voting rights and rights associated with a fair trial and equality. Social and economic rights typically refer to rights to health, education, culture, housing, social assistance, and nutrition. Those claiming that $\mathrm{s} .35$ requires government to provide social and economic benefits to Aboriginal people may well characterize Aboriginal rights as social and economic rights, whereas those opponents of this view may seek to characterize s. 35 rights more in terms of civil and political rights.

Schachter v. Canada, [1992] 2 S.C.R. 679 at 721 [hereinafter Schachter].

Ibid.

This idea is not unfamiliar to the judiciary when cast in terms of remedial power; see, for example, Schachter, ibid. at 709 ("[i]n determining whether reading in is appropriate ..., the question is not whether courts can make decisions that impact on budgetary policy; it is to what degree they can appropriately do so"). 
The distinction between civil and political rights and social and economic rights owes its origins in part at least to the postwar decision to split the 1948 Universal Declaration of Human Rights ${ }^{15}$ into two treaties: the International Covenant on Civil and Political Rights, ${ }^{16}$ and the International Covenant on Economic, Social and Cultural Rights. ${ }^{17}$ The first treaty deals with civil and political rights subject to determinations of compliance by a quasi-judicial body, the Human Rights Committee, on the basis of individual complaints. ${ }^{18}$ The second treaty lists economic, social, and cultural rights and initially provided no equivalent right of individual petition and limited its monitoring mechanism to a state report procedure. ${ }^{19}$

As stated, the distinction between civil and political rights and social and economic rights turns on the nature of the interests they protect. Broadly speaking, civil and political rights protect an individual's formal ability to participate in civil and political life. By protecting freedom of conscience, religion, expression, assembly, and association, prohibiting certain forms of discrimination, and subjecting the exercise of state power to the rule of law and principles of fundamental justice, civil and political rights purport to guarantee individual freedom and political democracy. In contrast, social and economic rights seek to identify and protect the fundamentals of economic and social well-being. The International Covenant on Economic, Social and Cultural Rights, for example, seeks to protect the right to work, the right to education and medical care, the right to social security, and rights to food, clothing and shelter. Social and economic rights thus seek to protect interests associated with employment, education, health, housing, nutrition and economic well-being.

Many have pointed out the intimate relationship between civil and political rights and social and economic rights. As stated by Frank Scott in 1949, "[w]e are more aware today of the foolishness of pretending that a man is 'free' when he is unemployed and without income through no fault of his own, or when he cannot pay for good health or good education for his children."20 Michael MacMillan claims an instrumental relation between the two sets of rights:

It is virtually a commonplace observation that the traditional political rights are chimerical in the absence of a minimum level of socioeconomic subsistence: that some minimal level of education is a prerequisite to the effective enjoyment of freedom of speech, or that an adequate supply of food and shelter is necessary for political liberty to be meaningful. If the political rights are of paramount importance, then so too are the major social rights simply because they are necessary prerequisites to the exercise of the political rights. ${ }^{21}$

UNGA Res. 217 (III), UNGAOR, 3rd Sess., Supp. No. 13 at 71, UN Doc. A/810 (1948). 19 December 1966, 999 U.N.T.S. 171 (entered into force 23 March 1976). 16 December 1966, 993 U.N.T.S. 3 (entered into force 3 January 1976).

See generally D. McGoldrick, The Human Rights Committee: Its Role in the Development of the International Covenant on Civil and Political Rights (Oxford: Clarendon Press, 1991).

See generally P. Alston \& G. Quinn, "The Nature and Scope of States Parties' Obligations Under the International Covenant on Economic, Social and Cultural Rights" (1987) 9 Hum. Rts. Q. 156. "Dominion Jurisdiction Over Human Rights and Fundamental Freedoms" (1949) 27 Can. Bar Rev. 497 at 507.

"Social versus Political Rights" (1986) 19 Can. J. Pol. Sci. 283 at 285-86. 
Despite this relationship, it is often thought that civil and political rights are negative rights, whereas social and economic rights are positive rights. As indicated by the preceding discussion of positive dimensions of legal rights, however, some civil and political rights create positive obligations on the state. Moreover, social and economic rights often engender obligations typically associated with negative rights. For example, a right to housing may possess positive dimensions in so far as it requires government to provide housing, but it also may possess negative dimensions in so far as it requires government to refrain from levelling existing homes. ${ }^{22}$

\section{JUSTICIABILITY CONCERNS}

Although it remains very much a live interpretive issue in the context of the Charter, ${ }^{23}$ courts generally have been reluctant to invest civil and political rights with social and economic content. Judicial reluctance stems in part from uncertainty surrounding the justiciability of social and economic matters, i.e., the extent to which they are suitable for judicial determination. ${ }^{24}$

Concerns about justiciability generally question either the institutional legitimacy or the institutional competence of the judiciary. ${ }^{25}$ Concerns grounded in institutional legitimacy question the justice of presenting a set of rights to the judiciary, an unelected body, in order to require legislatures to pursue particular political programs. For example, one scholar has stated that having the judiciary "declare that a government is

Compare Olga Tellis, [1985] 2 Supp. S.C.R. 51 (India) (refusing to respect a right to be heard prior to the eviction of sidewalk dwellers violated right to a livelihood and right to work).

The Supreme Court of Canada has expressly refrained from stating whether 5.7 of the Charter, guaranteeing a right to security of the person, protects "economic rights fundamental to human life or survival": see Irwin Toy v. Québec, [1989] 1 S.C.R. 927 at 1003-1004. It added that,

[1]ower courts have found that the rubric of "economic rights" embraces a broad spectrum of interests, ranging from such rights, included in various international covenants, as rights to social security, equal pay for equal work, adequate food, clothing and shelter, to traditional property-contract rights. To exclude all of these at this early moment in the history of Charter interpretation seems to us to be precipitous (at 1003).

Compare Finlay v. Canada, [1990] 2 F.C. 790 at 816 (F.C.A.) ("it must not be blithely supposed that it is necessarily in the public interest to bleed those who live at or below the poverty line as a purgative for social health, even if the bleeding is only at a little at a time and only once a month"). See also H. Orton, "Section 15, Benefits Programs and Other Benefits at Law: The Interpretation of Section 15 of the Charter since Andrews" (1990) 19 Man. L.J. 288; I. Johnstone, "Section 7 of the Charter and Constitutionally Protected Welfare" (1988) 46 U.T. Fac. L. Rev. 1; M. Jackman, "The Protection of Welfare Rights Under the Charter" (1988) 20 Ottawa L. Rev. 257. See D.J. Galligan, Discretionary Powers: A Legal Study of Official Discretion (Oxford: Clarendon Press, 1990) at 241 (defining "non-justiciable" as "unsuited for adjudication").

See G. Otis, "La Charte et la modification des programmes gouvernementaux: l'exemple de l'injonction structurelle en droit américain" (1991) 36 McGill L.J. 1340 at 1357-60 (legitimacy versus efficacy); C. Scott \& P. Macklem, "Constitutional Ropes of Sand or Justiciable Guarantees? Social Rights in a New South African Constitution" (1992) 141 U. Penn. L. Rev. 1 (legitimacy versus competence); M. Minow, Making All the Difference: Inclusion, Exclusion, and American Law (lthaca: Comell University Press, 1990) at 241-51 (legitimacy versus competence); Jackman, supra note 23 at 330-37 (legitimacy versus competence); T.A. Cromwell, Locus Standi: $A$ Commentary on the Law of Standing in Canada (Toronto: Carswell, 1986) (legitimacy versus adequacy). 
lagging behind in creating the conditions under which a social right could be enjoyed" would raise "utterly political questions." 26

Legitimacy concerns can emanate from both conservative and progressive visions of society. Conservative critics of social and economic rights often decry the fact that social and economic rights would require state intervention in the market and a significant redistribution of wealth. ${ }^{27}$ Some progressive critics of social and economic rights fear the further legalization of politics, ${ }^{28}$ others warn that social and economic rights "are too vague to guarantee anything of substance, do not touch the complicated causes of poverty and disadvantage, and their symbolic message is at best ambiguous." 29

In contrast, concerns grounded in institutional competence speak to whether the judiciary is capable of making meaningful determinations regarding the nature and scope of certain types of rights, given their underlying interests and ensuing obligations. Social and economic rights are often characterized as vague in terms of the obligations they mandate, progressive and therefore requiring time to realize, and complex and diffuse in terms of the interests they protect. It is often argued that courts accordingly lack expertise or competence in adjudicating disputes involving social and economic rights, and that social and economic rights adjudication requires complex fiscal decision-making in which the judiciary is ill-suited to engage. ${ }^{30}$

Any discussion of the extent to which Aboriginal rights impose positive obligations on government to provide social and economic benefits to Aboriginal people is bound to refer to the distinction between negative and positive rights. Such a discussion is also bound to implicate the distinction between civil and political rights and social and economic rights, as well as concerns relating to the justiciability of social and economic rights. Nonetheless, these constitutional distinctions and principles do not fully capture what differentiates Aboriginal rights from their civil, political, social, and economic counterparts. Aboriginal rights, properly understood, are not civil and political rights, nor are they social and economic rights. As the next part of this article suggests,

E.W. Vierdag, "The Legal Nature of the Rights Granted by the International Covenant on Economic, Social and Cultural Rights" (1978) 9 Neth. Y.B. Int'l L. 69 at 92-93.

See, for example, R. Epstein, Takings: Private Property and the Power of Eminent Domain (Cambridge: Harvard University Press, 1985) at 307-12.

See, for example, M. Mandel, The Charter of Rights and the Legalization of Politics in Canada (Toronto: Wall \& Thompson, 1989); H. Glasbeek, "The Social Charter: Poor Politics for the Poor" in J. Bakan \& D. Schneiderman, eds., Social Justice and the Constitution: Perspectives on a Social Union for Canada (Ottawa: Carleton University Press, 1992) 115 at 123 ("it may turn out that a social charter becomes a way for government and others to avoid having to engage in transformative politics").

J. Bakan, "What's Wrong With Social Rights?" in Social Justice and the Constitution, ibid., 85 at 86.

See J. Frémont, "Les tribunaux et la Charte: le pouvoir d'ordonner la dépense de fonds publics en matières sociales et économiques" (1991) 36 McGill L.J. 1323; A. Petter, "The Politics of the Charter" (1986) 8 Supreme Court L.R. 473; H.I. Kalodner \& J.J. Fishman, eds., Limits of Justice: The Courts Role in School Desegregation (Cambridge: Ballinger Publishing, 1978); L.L. Fuller, "The Forms and Limits of Adjudication" (1978) 92 Harv. L. Rev. 353. 
Aboriginal rights reflect qualitatively different interests and concerns, which arguably possess unique positive dimensions.

\section{Postrive Dimensions of Aboriginal Rights}

Does s. 35 of the Constitution Act, 1982 recognize and affirm Aboriginal rights to receive certain social and economic benefits from government? One approach to this question, alluded to in the introduction of this article, is to suggest that Aboriginal rights recognized by s. 35 include rights to a wide array of social and economic benefits from federal, provincial or territorial governments. At least three factors support this view. First, the Crown already owes a number of positive obligations to Aboriginal peoples as a result of its fiduciary relationship. ${ }^{31}$ Second, it seems intuitively unfair to distribute social and economic benefits only to those Aboriginal peoples sufficiently powerful or fortuitous to enjoy either the benefit of treaty protection or legislative good will. ${ }^{32}$ Third, it is not unreasonable to suggest that the Canadian state ought to be constitutionally obliged to undo the damage wrought by colonization and ameliorate Aboriginal socio-economic disadvantage. ${ }^{33}$

Despite the attractiveness of this open-ended approach, it faces a number of formidable hurdles. First, the judiciary likely will be reluctant to view s. 35(1) in terms that require substantive and open-ended judicial scrutiny of social and economic policy. As stated in the previous part of this article, courts tend to raise concerns relating to institutional legitimacy and institutional competence when faced with claims that government is constitutionally obligated to provide a particular benefit to a group of people.

These concerns will be heightened in the context of Aboriginal rights adjudication. Concerns about the institutional legitimacy of the judiciary interpreting s. 35(1) in this manner will be exacerbated by the problematic justice of differential constitutional protection in this regard. Why should governments be constitutionally obligated to provide certain educational or health care benefits to Aboriginal people but not necessarily to non-Aboriginal people? Concerns about institutional competence of the judiciary will be magnified to the extent that claims relate not to a floor set of basic entitlements but to specific entitlements over and above what are provided as of statutory right to Aboriginal and non-Aboriginal people alike. These concerns will provide a powerful web of judicial resistance to viewing Aboriginal rights in social and economic terms. In the absence of a more restrained approach, the judiciary likely will

31 For a discussion of the Crown's fiduciary obligations, see generally L.l. Rotman, Parallel Paths: Fiduciary Doctrine and the Crown - Native Relationship in Canada (Toronto: University of Toronto Press, 1996). Compare R. Dworkin, Law's Empire (Cambridge: Harvard University Press, 1986) (criticizing distributions that result in "checkerboard" justice).

33

Compare B. Schwartz, First Principles, Second Thoughts: Aboriginal Peoples, Constitutional Reform and Canadian Statecraft (Montreal: Institute for Research on Public Policy, 1986) at 48 ("Most Canadians would respond better to a claim for fiscal transfers to aboriginal governments if they were characterized as a step towards the improvement of the lives and opportunities of aboriginal peoples, rather than as the correction of a wrong done by Canadians in the past"). 
shy away from constitutionally requiring government to provide social and economic benefits to Aboriginal people.

Second, and related to the above, an open-ended approach to the issue does not fit comfortably with the jurisprudence to date addressing the nature and scope of Aboriginal rights recognized and affirmed by s. 35 . In $R$. v. Sparrow, the Supreme Court of Canada held that s. 35(1) recognizes and affirms existing Aboriginal practices that are integral to Aboriginal identity. ${ }^{34}$ The Court accepted anthropological evidence to the effect that, "for the Musqueam, the salmon fishery has always constituted an integral part of their distinctive culture."35 In contrast to such practices, social and economic rights are designed to ensure that the state provides individuals and communities with basic social and economic benefits. At first glance, Aboriginal rights appear to address a different set of purposes and interests than those served by social and economic rights. Any claim that s. 35(1) requires government to provide a social or economic benefit to Aboriginal people needs to link the benefit in question to the purposes served by the provision. This requires an analysis of the interests protected

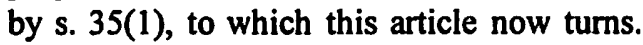

\section{A. REAding SPARRow}

Whether s. 35(1) recognizes rights to receive social and economic benefits ought to turn on the interests that $\mathrm{s} .35$ is designed to protect. ${ }^{36}$ Jurisprudence on the nature and scope of s. 35 is still in its early stages and, as a result, any discussion of the interests that the judiciary is likely to identify as underlying the provision is bound to be tentative and speculative. This section identifies and discusses three possible interests underlying the constitutional recognition and affirmation of existing Aboriginal and treaty rights: Aboriginal identity, Aboriginal territory, and Aboriginal sovereignty. It then explores how these interests might relate to claims that government is constitutionally required to provide certain social and economic benefits to Aboriginal people.

For all of its historic significance, the Supreme Court of Canada's decision in $R$ v. Sparrow was remarkably terse on what constitutes an Aboriginal right. As stated, the Court held that s. 35(1) recognizes and affirms an activity, namely fishing, that, "for the Musqueam, ... has always constituted an integral part of their distinctive culture."37 A narrow interpretation of this holding is that s. 35(1) only recognizes and affirms

34 [1990] 1 S.C.R. 1075 [hereinafter Sparrow].

35 Ibid. at 1099. See also $R$ v. Van der Peet, [1996] 2 S.C.R. 507 [hereinafter Van der Peet].

36 Compare Sparrow, supra note 34 at 1106 ("[t]he approach to be taken with respect to interpreting the meaning of $s$. $35(1)$ is derived from general principles of constitutional interpretation, principles relating to aboriginal rights, and the purposes behind the constitutional provision itself'), and R. v. Big M Drug Mart Ltd., [1985] I S.C.R. 295 at 344 ("[t]he meaning of a right or freedom guaranteed by the Charter" is "to be ascertained by an analysis of the purpose of such a guarantee" and "in the light of the interests it was meant to protect"). See also Van der Peet, ibid. Supra note 34 at 1099. 
existing Aboriginal practices integral to Aboriginal identity. ${ }^{38}$ This reading of Sparrow would make it extremely difficult to assert that $\mathrm{s}$. 35(1) requires governments to provide certain social and economic benefits to Aboriginal people independently of any treaty obligations. One would be required to demonstrate that receipt of a particular social and economic benefit is an existing Aboriginal practice integral to Aboriginal identity.

However, Sparrow can be interpreted more broadly by focusing on the reason why the Court was willing to view the practice of fishing as a constitutional right. In the Court's opinion, the practice deserved the status of a constitutional right because it was and is integral to Aboriginal culture or identity. The interest underlying the right to fish, in other words, is Aboriginal identity. This suggests that preservation and protection of Aboriginal identity is an interest or value that ought to shape s. 35 interpretation. This conceptually opens the door for constitutional recognition of Aboriginal rights to receive certain social and economic benefits. It may well be the case that a convincing argument could be made that certain social and economic benefits provided to Aboriginal people by government are essential to the preservation and protection of Aboriginal identity. ${ }^{39}$ Withdrawal of such a benefit in some circumstances ${ }^{40}$ might then constitute an interference with Aboriginal identity and thus an infringement of $s$. 35. It would then require justification in accordance with the tests set out in Sparrow in order to withstand constitutional scrutiny. ${ }^{41}$

A still broader interpretation of the Court's holding is that Aboriginal identity is an interest, but not the only interest, that s. 35(1) is designed to protect. Whether this is the case will turn on what the Court sees to be the purpose of $s .35(1)$. In the recent decision of $R$. v. Van der Peet, the Court stated that the purpose of s. 35(1) was to "provide the constitutional framework through which the fact that aboriginals lived on the land in distinctive societies, with their own practices, traditions and cultures, is ... reconciled with the sovereignty of the Crown." ${ }^{42}$ In light of this purpose, other

An even narrower reading would focus on the fact that the Court noted that fishing "always constituted an integral part of [Musqueam] ... culture," ibid. [emphasis added]. See, for example, Delgamuukw v. British Columbia (1991), 79 D.L.R. (4th) 185 at 422 (B.C.S.C.), McEachern C.J.B.C., rev'd(1993), 104 D.L.R. (4th) 470 (B.C.C.A.) (Aboriginal practice must have existed for a "long, long time" prior to contact). See also Van der Peet, supra note 35 (practices, customs and traditions must have existed pre-contact).

Compare MacDonald v. City of Montréal, [1986] 1 S.C.R. 460 at 521, Wilson J. dissenting ("there is substantial support in legal theory for the appellant's submission that right and duty are correlative terms and ... if s. 133 confers a right on a litigant to use his or her language in court ..., then there is a correlative duty on the state to respect and accommodate that right").

The Court in Sparrow, supra note 34 at 1112, suggested that interferences with Aboriginal rights must be "unreasonable" or "undue" in order to constitute a prima facie infringement of s. 35(1). According to Sparrow, ibid. at 1110, government action interfering with the exercise of an Aboriginal right must possess a "valid objective" and must accord Aboriginal people top priority after the implementation of such an objective. In addition, the Court signalled that it might inquire into

whether there has been as little infringement as possible in order to effect the desired result; whether, in a situation of expropriation, fair compensation is available; and, whether the aboriginal group in question has been consulted with respect to the ... measures being implemented." (at 1119). 
interests arguably implicated by s. 35 include Aboriginal territory and Aboriginal governance.

With respect to Aboriginal territory, one issue with which the judiciary is grappling is the relationship between traditional Canadian legal understandings of Aboriginal title and the constitutional recognition of Aboriginal rights accomplished by s. 35(1). Does s. 35(1) constitutionalize Aboriginal title in toto? Or does s. 35(1) constitutionalize particular rights to engage in particular practices on lands to which Aboriginal people enjoy title? ? $^{43}$

The former approach would result in the constitutionalization of Aboriginal peoples' interests in their territories, including the freedom to decide how to use one's territory. As stated by Chief Justice Marshall of the United States Supreme Court in Johnson v. $M^{\prime}$ 'Intosh ${ }^{44}$ and affirmed by Dickson J. (as he then was) in Guerin v. R. ${ }^{45}$ Aboriginal peoples are "the rightful occupants of the soil, with a legal as well as just claim to retain possession of it, and to use it according to their own discretion." The latter approach would result in the disaggregation of the bundle of rights traditionally referred to by Canadian law as Aboriginal title in order to elevate some rights of use to constitutional status.

For present purposes, the relevance of this ambiguity lies in the fact that it reflects uncertainty regarding the extent to which the preservation and protection of Aboriginal territory is an interest underlying the constitutional recognition and affirmation of Aboriginal rights. Yet insofar as Aboriginal identity is inextricably linked to the land, Aboriginal territory is as fundamental a value as Aboriginal identity. Put simply, the more the judiciary is willing to view Aboriginal territory as an interest that s. 35(1) is designed to protect, the easier it will be to persuade courts to require governments to provide Aboriginal peoples with social and economic benefits that are essential to the effective enjoyment of Aboriginal territory.

With respect to Aboriginal sovereignty as a third interest furthered by constitutional recognition and affirmation of existing Aboriginal rights, this article does not need to rehearse arguments in favour of viewing s. 35(1) as recognizing an inherent right of self-government. ${ }^{46}$ It suffices to say that respect for Aboriginal sovereignty underlies many arguments in favour of the inherent right of self-government. If the purpose of s. 35(1) is to acknowledge constitutionally the fact that Aboriginal peoples participated in distinctive societies prior to European contact and were sovereign nations prior to to aboriginal title fall within the conceptual framework of aboriginal rights, aboriginal rights do not exist solely where a claim to aboriginal title has been made out"). 21 U.S. (8 Wheat.) 543 (1823). [1984] 2 S.C.R. 335 at 378 [emphasis added] [hereinafter Guerin].

See Report of the Royal Commission on Aboriginal Peoples, Volume 2: Restructuring the Relationship, Part 1 (Ottawa: Minister of Supply and Services Canada, 1996) at 105-244, and authorities cited therein. 
that time, viewing s. 35(1) as recognizing an inherent right of self-government would further this purpose. ${ }^{47}$

Constitutional recognition of an inherent right of self-government may well implicate certain positive social and economic obligations on the part of federal, provincial and territorial governments. Non-Aboriginal governmental action in the area of base funding could have a critical effect on the exercise of an Aboriginal right of self-government. In the words of C.E.S. Franks,

The value of aboriginal self-government is its potential for performing essential and unusual functions for unique and disadvantaged parts of the Canadian mosaic. It is not a means for saving money. To regard [it] as such could perpetuate and entrench the harms of the present system. Aboriginal selfgovernment might well cost more, rather than less. Small governments are in their nature costly. The special functions of aboriginal self-governments in relation to cultural preservation and adaptation, and to economic development, will make them especially costly. So also will the factors of remoteness, the health and social breakdown problems of aboriginal communities, and the many other factors that have caused, and are part of, the present problems....

Clearly, funding arrangements, including the strings attached, the structure and form of negotiations, the clarity, objectivity and faimess of the funding formula, and the arbitrariness of the federal government in giving or withholding funds, will have a crucial effect on the success or failure of aboriginal self-government. ${ }^{48}$

In light of this fact, it would not be unreasonable to suggest that the positive dimensions of an Aboriginal right of self-government include obligations on the Crown to reach fiscal arrangements with Aboriginal governments to ensure that the right of self-government is not illusory. Such obligations may well include the provision of certain social and economic benefits, especially those which relate to base funding of Aboriginal governmental power.

It would be perhaps easier to view such obligations as constitutional if and when they are contained in self-government agreements rather than as free-standing Aboriginal rights. In this vein, reference ought to be made to the Draft Legal Text of the Charlottetown Accord, which proposed to impose a constitutional obligation on governments to bargain in good faith to reach agreements addressing inter alia "economic and fiscal arrangements," and to provide that rights contained therein could

See $R$. v. Pamajewon, [1996] 2 S.C.R. 821 at 832-33 (paras. 24, 25) ("[a]ssuming without deciding that s. 35(1) includes self-government", it must be "an element of a practice, custom or tradition integral to the distinctive culture of the aboriginal group claiming the right" (citing Van der Peet, supra note 35 at 549 (para. 46)).

48 Public Administration Questions Relating to Aboriginal Self-Government (Kingston: Institute of Intergovernmental Relations, 1987) at 68-70. 
constitute "treaty rights" within the meaning of s. 35(1) of the Constitution Act, $1982 .{ }^{49}$

The claim advanced thus far is that governments may well be constitutionally obligated to provide certain social and economic benefits to Aboriginal people. Such obligations would only be triggered if they are essential to the fundamental purpose of s. 35(1), which is to constitutionally acknowledge the fact that Aboriginal people lived on the land in distinctive societies with unique cultures prior to European contact. However, a sceptic could agree that such an acknowledgement requires treating Aboriginal identity, territory and sovereignty as interests worthy of constitutional protection, but argue, as alluded to in the introduction of this article, that respect for these interests should not result in the imposition of any constitutional requirements on government to provide economic and social benefits to Aboriginal people. Concerns relating to institutional legitimacy and institutional competence militate against interpreting S. 35(1) to require government to provide such benefits. Any benefits in this regard ought to be the product of negotiation or legislation. If negotiated, such benefits could constitute treaty rights and receive independent recognition as such by s. 35. If legislated, such benefits could be withdrawn or altered without the consent of Aboriginal peoples.

However, the approach suggested by the sceptic seems unduly narrow. It overlooks the fact, discussed in Part II of this article, that all rights possess positive dimensions and that therefore the relevant inquiry is not whether a right imposes positive obligations on government but whether the right contemplates the particular positive obligation in question. It also overlooks the fact that domestic and international law already imposes significant positive obligations on governments to provide certain forms of social and economic benefits to Aboriginal people. Domestic obligations flow from the fiduciary obligation governing the Crown's relationship with Aboriginal peoples. International obligations flow from international human rights documents that directly or indirectly call on the Canadian state to take positive action to improve the social and economic status and condition of Aboriginal peoples within its national borders. The existence of both sets of obligations dampens concerns about the legitimacy of constitutionally requiring government to provide social and economic benefits to Aboriginal people. Each is addressed in turn.

\section{B. Fiduciary Obligations of the Crown}

Canadian law provides that the Crown is under a fiduciary obligation with respect to Aboriginal peoples. While the precise contours of this obligation remain unclear, it would appear to impose a number of positive obligations on the Crown. Fiduciary duties with respect to Aboriginal peoples have been recognized in at least three

49 Draft Legal Text, Charlottetown Accord (9 October 1992), s. 29 (repealing and substituting ss. 35.2(1)(c), 35.2(6), inter alia). Compare Reference Re Canada Assistance Plan (B.C.), [1991] 2 S.C.R. 525 (federal government can unilaterally change the terms of an intergovermmental agreement setting out the amount of money owed to certain provinces under a cost-sharing arrangement in relation to social assistance). 
different contexts. First, it is well-settled that the federal Crown is under a fiduciary obligation to act in the interests of an Indian band when the band surrenders land to the Crown for third party use. ${ }^{50}$ Second, reasons at trial in Delgamuukw v. British Columbia provide that, in some contexts at least, the provincial Crown owes fiduciary obligations to Aboriginal peoples upon the unilateral extinguishment of Aboriginal rights with respect to land. ${ }^{51}$ Third, jurisprudence under s. 35(1) of the Constitution Act, 1982 suggests that governmental action that interferes with the exercise of Aboriginal rights recognized and affirmed by s. 35(1) creates fiduciary duties on the government responsible for the interference in question. ${ }^{52}$

With respect to this third context, the Court in Sparrow stated that,

[t]he sui generis nature of Indian title, and the historic powers and responsibility assumed by the Crown constituted the source of such a fiduciary obligation. In our opinion, Guerin, together with $R$. v. Taylor and Williams (1981), 34 O.R. (2d) 360 [a case addressing treaty interpretation], ground a general guiding principle for S. 35(1). That is, the Government has the responsibility to act in a fiduciary capacity with respect to aboriginal peoples. The relationship between the Government and aboriginals is trust-like, rather than adversarial, and contemporary recognition and affirmation of aboriginal rights must be defined in light of this historic relationship. ${ }^{33}$

Several important principles emerge from the Court's reasons in Sparrow. First, Sparrow is an indication that the conservative view that fiduciary obligations are triggered only upon the voluntary surrender of Aboriginal land is to be supplemented with a more expansive view that fiduciary obligations are also triggered upon unilateral extinguishments of Aboriginal rights. If the Crown owes fiduciary obligations to Aboriginal people when it unilaterally interferes with the exercise of Aboriginal rights, then a fortiori the Crown, at least after 1982, owes certain fiduciary obligations when it unilaterally extinguishes Aboriginal rights.

Second, Sparrow suggests that consultation with affected Aboriginal people will be a potentially important factor in seeking to justify s. 35(1) infringements. The Court suggested that a relevant inquiry in determining whether an infringement of Aboriginal rights is justified is "whether the aboriginal group in question has been consulted with respect to the conservation measures being implemented." ${ }^{44}$ According to Dickson C.J.C. and La Forest J.,

[t]he aboriginal peoples, with their history of conservation-consciousness and interdependence with natural resources, would surely be expected, at the least, to be informed regarding the determination of an appropriate scheme for the regulation of the fisheries.ss

Guerin, supra note 45.

Supra note 38.

Sparrow, supra note 34.

lbid. at 1108.

Ibid. at 1119.

Ibid. 
The Court was careful to indicate that whether consultation was required would depend "on the circumstances of the inquiry," and to situate the need for consultation within a broader call for "sensitivity to and respect for the rights of aboriginal peoples on behalf of the government, courts and indeed all Canadians." "36

The steady expansion of the concept of a fiduciary relationship may well result in the establishment of "a general fiduciary duty" on the part of the Crown "toward native people to protect them in the enjoyment of their aboriginal rights and in particular in the possession and use of their lands." ${ }^{57}$ The Court's reasons in Sparrow certainly are

consistent with this characterization. ${ }^{58}$ A general duty of protection likely would involve a number of specific positive obligations to Aboriginal people. Even if these positive obligations did not include the provision of social and economic benefits to Aboriginal people, their presence would lend legitimacy to the view that government in some circumstances ought to be constitutionally required to provide certain social and economic benefits to Aboriginal people.

\section{InTERNATIONAL Legal Obligations}

Emerging international legal principles also support the legitimacy of viewing government as constitutionally required to provide certain social and economic benefits to Aboriginal people. The Draft Declaration on the Rights of Indigenous Peoples, prepared by a sub-commission of the United Nations Commission on Human Rights, proposes to recognize that "Indigenous peoples have the right to self-determination in accordance with international law, subject to the same criteria and limitations as applied to other peoples in accordance with the Charter of the United Nations." 59 Accordingly, the Draft Declaration proposes to recognize inter alia indigenous rights of autonomy and self-government, the right to manifest, practice and teach spiritual and religious traditions, rights to territory, education, language and cultural property, and the right to maintain and develop indigenous economic and social systems. ${ }^{60}$ It is difficult to imagine that these rights will not require government to provide certain social and

Ibid.

57 B. Slattery, "Understanding Aboriginal Rights" (1987) 66 Can. Bar Rev. 727 at 753.

Reference should also be made to the landmark decision by the High Court of Australia in Mabo v. Queensland (1992) 175 C.L.R. 1, where six members of a seven-member panel agreed that Australian common law recognizes a form of Aboriginal title which, in cases where it has not been extinguished, protects Aboriginal use and enjoyment of ancestral land. Three of the six in the majority (Deane, Toohey, and Gaudron JJ.) would have gone further to recognize a general fiduciary obligation on the part of the Crown that exists independently of any "obligation arising as a result of particular action or promises by the Crown" (at 204). In contrast to the approach taken in Delgamuukw, extinguishment or impairment of Aboriginal rights to land "would not be a source of the Crown's obligation, but a breach of it" (at 205). The other three judges comprising the majority (Brennan J., Mason C.J., and McHugh J. concurring), together with Dawson J. dissenting, did not agree with this approach, holding that the Crown is not in breach of any duty when it exercises sovereign authority and extinguishes Aboriginal rights. 1993) (prepared by the Chair-Rapporteur of the Working Group on Indigenous Populations). Ibid. 
economic benefits to Aboriginal people. Indeed, art. 37 of the Draft Declaration provides that:

States shall take effective and appropriate measures, in consultation with the indigenous peoples concerned, to give full effect to the provision of this Declaration. The rights recognized herein shall be adopted and included in national legislation in such a manner that indigenous peoples can avail themselves of such rights in practice. ${ }^{61}$

Similarly, numerous articles of the United Nations Charter affirm cultural cooperation and cultural development. ${ }^{62}$ Article 27 of the International Covenant on Civil and Political Rights recognizes rights of members of "ethnic, religious or linguistic minorities ... to enjoy their own culture, to profess and practise their own religion, [and] ... to use their own language." ${ }^{63}$ The U.N. Convention Against Genocide provides added support for the concept of cultural autonomy, ${ }^{64}$ as does the UNESCO Declaration of Cultural Co-operation, which affirms a right and duty of all peoples to protect and develop minority cultures throughout the world. ${ }^{65}$ The U.N. Convention on Racial Discrimination calls for positive governmental action to "ensure the adequate development and protection of certain racial groups or individuals belonging to them."

In addition, Convention 107 of the International Labour Organization, ${ }^{67}$ adopted in 1957, while advocating the "integration" of indigenous populations into national communities, also calls upon governments to develop co-ordinated and systematic action to protect indigenous populations and to promote their social, economic and cultural development. ${ }^{68}$ While the ILO Convention may now appear somewhat dated in its emphasis on integration, ${ }^{69}$ its existence suggests some degree of support at the

Ibid.

Charter of the United Nations, 26 June 1945, Can. T.S. 1945 No. 7, 59 Stat. 1031, 145 U.K.F.S. 805 , arts. $13,55,57$, and 73 .

Supra note 16 at 179.

Convention on the Prevention and Punishment of the Crime of Genocide, 9 December 1948, 78 U.N.T.S. 277 (entered into force 12 January 1951). Art. II defines "genocide" as "acts committed with intent to destroy, in whole or in part, a national, ethnical, racial or religious group, as such..." (ibid. at 280). For links between the concept of genocide and the treatment of American Indians, see L.H. Legters, "The American Genocide" in F.J. Lyden \& L.H. Legters, eds., Native Americans and Public Policy (Pittsburgh: University of Pittsburgh Press, 1992) 101.

Declaration of the Principles of International Cultural Cooperation, UN ESCOR, 14th Sess., UN Doc. ST/HR/1/Rev.3 (1988); cited in Human Rights: A Compilation of International Instruments (New York: United Nations, 1988) at 409.

International Convention on the Elimination of All Forms of Racial Discrimination, opened for signature 7 March 1966, 660 U.N.T.S. 195, art. 2, para. 2 at 218 (entered into force 4 January 1969).

The Protection and Integration of Indigenous and Other Tribal and Semi-Tribal Populations in Independent Countries, Conventions and Recommendations Adopted by the International Labour Conference, 1919-66 (Geneva: ILO, 1966) at 901 and 909. Canada is not party to the Convention. Ibid., arts. 2(1), 2(2).

For an assessment of the ILO Convention, see P. Thomberry, International Law and the Rights of Minorities (Oxford: Clarendon Press, 1991) at 334-68. 
level of international customary law for recognition of positive governmental obligations to provide certain social and economic benefits to Aboriginal people.

The International Labour Organization recently revised Convention 107 in its Convention No. 169 of $1989 .{ }^{70}$ It recognizes "the aspirations of [indigenous] peoples to exercise control over their own institutions, ways of life and economic development and to maintain and develop their identities, languages and religions, within the frameworks of the States in which they live." 71 It then lists an impressive range of rights that attach to Aboriginal people and responsibilities that attach to governments in relation to Aboriginal people which would facilitate the protection of Aboriginal ways of life. ${ }^{72}$

\section{Institutional Competence REvisited}

While the presence of domestic and international positive obligations may well placate at least some concerns about the legitimacy of interpreting $\mathrm{s}$. $35(1)$ as requiring government to provide certain social and economic benefits to Aboriginal people, the sceptic could still advance cogent arguments based on the incapacity of the judiciary to effectively adjudicate such matters. Concerns of institutional competence are still likely to have a major effect on the extent to which s. 35(1) is interpreted to require governmental action in this respect. It suffices to say that the more closely tied the benefit is to an interest underlying s. 35 , the more comfortable the judiciary will be in requiring government to provide the benefit. But this comfort likely will never completely erase lingering concerns about the competence and capacity of the judiciary to order positive governmental action in relation to social and economic matters.

It should be noted that efforts have been made to demystify complications associated with the judicial role in the context of the interpretation and enforcement of social and economic rights, and to point out that social and economic rights possess more precision and clarity than their critics suggest. A number of studies have attempted to provide greater clarity and precision to the nature of obligations that social and

n International Labour Organization, Convention No. 169 (27 June 1989), Convention Concerning Indigenous and Tribal Peoples in Independent Countries (entered into force 5 September 1990). Canada is not yet a party to the Convention, but, in the words of one scholar, it arguably "represents a core of expectations that are widely shared internationally and, accordingly, it reflects emergent customary intemational law generally binding upon the constituent units of international community" (S.J. Anaya, "Canada's Fiduciary Obligations Towards Indigenous Peoples in Quebec Under International Law" in Royal Commission on Aboriginal Peoples, Canada's Fiduciary Obligations to Aboriginal Peoples in the Context of Accession to Sovereignty by Quebec, Volume I: International Dimensions (Ottawa: Minister of Supply and Service Canada, 1995) at 20). Ibid. at fifth preambular paragraph.

72 See Anaya, supra note 70; L. Swepston, “A New Step in the International Law on Indigenous and Tribal Peoples: ILO Convention No. 169 of 1989" (1990) 15 Okla. City Univ. L. Rev. 677. 
economic rights tend to generate. ${ }^{73}$ Such studies may well assist in delineating the nature and scope of governmental obligations in the context of s. 35(1).

In this vein, Henry Shue has suggested that social and economic rights trigger a three-fold structure of obligations on government. ${ }^{74}$ The first type of obligation that a social or economic right might impose on government is a duty to respect the particular right in question. This duty is negative in nature, in that it requires government not to infringe the right. The second type of obligation is a duty of protection, and it requires government to prevent the right in question from being infringed by private actors. The third obligation, a duty to fulfill the right, is truly positive, and translates into governmental obligations to provide certain benefits. ${ }^{75}$ This last obligation can be rendered even more precise by imposing on governments a duty to "take steps" toward the fulfillment of the right. ${ }^{76}$ It may well be possible to articulate a structure of obligations in the context of Aboriginal rights adjudication to assist in rendering more precise the nature of positive governmental obligations to provide certain benefits.

\section{CONCLuSION}

The aim of this article was to reflect on whether constitutional recognition of Aboriginal rights imposes positive constitutional obligations on the Canadian state to provide economic or social benefits to Aboriginal people. It sought to steer a middle ground between the view that the Canadian Constitution imposes a wide array of social and economic obligations on government and the view that the Constitution simply imposes various duties of non-interference. It argued that s. 35(1) constitutionally recognizes more than what are often referred to as negative rights, and recognizes that Aboriginal rights possess positive dimensions. Such positive dimensions may include requiring government in some circumstances to provide certain social and economic benefits to Aboriginal people. Whether a particular social or economic benefit is required by s. 35(1) will depend on whether it is integral to one or more of the purposes or interests served by the constitutional recognition and affirmation of Aboriginal rights. In this light, Aboriginal identity, territory, and sovereignty ought to be the touchstones for determining whether, and the extent to which, the Canadian state is constitutionally required to provide a particular social or economic benefit to Aboriginal people.

See, for example, D. Türk, U.N. Commission on Human Rights, Preliminary Report on the Realization of Economic, Social and Cultural Rights, U.N. Doc. E/CN.4/Sub.2/1989/19 (1989); D. Türk, Progress Report on the Realization of Social, Economic, and Cultural Rights, U.N. ESCOR, Comm'n. on Hum. Rts., 42d Sess., Agenda Item 7 at 4, U.N. Doc. E/CN.4/Sub.2/1990/19 (1990). Basic Rights: Subsistence, Affluence, and U.S. Foreign Policy (Princeton: Princeton University Press, 1980).

Compare MacMillan, supra note 21 at 300 (placing the onus on the state to protect the exercise of social rights).

See, for example, The Limburg Principles on the Implementation of the International Covenant on Economic, Social and Cultural Rights, U.N. ESCOR, Comm'n. on Hum. Rts., 43d Sess., Annex, Agenda Items 8 \& 18 at 1, U.N. Doc. E/CN.4/1987/17 (1987) (obligation to fulfill is immediate only with respect to the most vulnerable). 